UDC: $33: 316: 330.322: 336$

JEL Classification: M140, E220

http://doi.org/10.21272/mmi.2019.2-05

\author{
Valeriya Fadyeyeva, \\ Adam Mickiewicz University in Poznan, Poland
}

\title{
CORPORATE SOCIAL RESPONSIBILITY AS THE BASIS OF INNOVATIVE DEVELOPMENT OF MODERN COMPANIES: LITERATURE REVIEW AND EMPIRICAL STUDY FROM UKRAINE
}

Abstract. During several decades corporate social responsibility (CSR) has passed a long way from the theoretical concept of several scientists and entrepreneurs to the integrative part of the activity of the large business. Being a contemporary and innovative strategy CSR has already recommended itself as an effective tool for the positive overall perception of the company by stakeholders and consumers. However, the direct economic impact of CSR e.g. its relationship with corporate financial performance still remains unclear. Thereby this article summarizes the long discussion about the influence of CSR on the corporate financial performance (CFP) and shows the current state of CSR in the largest companies of the Ukrainian market. The main purpose of the research is to estimate the role of corporate social responsibility in the innovative development and international diversification of the companies regarding their corporate financial performance by analyzing most relevant publications and main economic indicators of the largest national and international companies of the Ukrainian market. Consequently, the object of the study is CSR in the world and in Ukraine. The article comprises of two-part - theoretical and empirical. For the theoretical analysis literature review was performed via Google Scholar search tool by key words connected to CSR; empirical analysis of the CSR levels in Ukrainian companies included 100 largest firms according to Top-200 Ukraine 2017. Two indicators were estimated - the presence of the information on theirs official web-pages about CSR/sustainable development programs and the presence of the annual or periodical (several years) reports about CSR/sustainable development programs. After the exclusion of 12 enterprises with state ownership and 5 without relevant information, 83 companies composed 2 study groups: \#1 - TNCs and their subsidiaries, - 21 companies, and \#2 - other, - 62 companies. Moving to the results literature review showed that up to date a bigger part of the evidence declares the positive CSR and CFP. However, still, some studies failed to confirm this correlation thus issues about this relationship remains partly uncertain. Nevertheless, all authors admitted that today CSR is one of the basic components of developmental strategies. The empirical study of the largest Ukrainian companies showed that levels of CSR significantly differs between TNCs with subsidiaries and national large business $(p=000,5)$ with higher levels in the first group. That means that CSR could be considered as an integral part of innovative management and international diversification of a firm. This article highlights one of the few studies about the current state of CSR in Ukraine, emphasized the important direction of further research in the field of corporate social responsibility in Ukraine. In spite of the scientific role, the results of this research may be useful for specialists in strategic planning, CEO's, financial managers.

Keywords: corporate social responsibility, CSR standards, corporate financial performance, investment attractiveness, CSR in Ukraine.

Introduction. The age of the third industrial revolution poses many challenges for conventional economic systems and political regimes. Globalization, regional integration, shift to the intellectual work and machine production lead to the strong increase of the social role of the large business, especially transnational corporations (TNC). The Ukrainian economy, as well as the political system, remain at the transitional state between socialistic Soviet Union model and capitalistic Western pattern. Consequently, it meets a complex problem to catch up with economies of western neighbours in the fast-changing world.

Being the strongest player in the international economy, TNC controls $70 \%$ of global trade, $55 \%$ of world production and $75 \%$ of global exchange in intellectual technologies. Net profit of the largest TNCs exceeds the annual budgets of some countries. These circumstances create unique opportunities for large national business and TNCs to influence on the social sector of many countries. Such opportunities lead

Cite as: Fadyeyeva, V. (2019). Corporate Social Responsibility as the Basis of Innovative Development of Modern Companies: Literature Review and Empirical Study from Ukraine. Marketing and Management of Innovations, 2, 52-61. http://doi.org/10.21272/mmi.2019.2-05 

Review and Empirical Study from Ukraine

to the new obligation for them - conduct their activity in a socially responsible way that is good know as corporate social responsibility (CSR).

Ukrainian national economy has many characteristic features including the distribution of shares of large, medium and small business. While the medium and small business (MSB) create $79.8 \%$ of all working places, they provide only 15\% GDP. MSB in Ukraine accounts for about $99.8 \%$ of all national business entities that even exceed such number in European countries. In the same time, according to the official statistics in 2012, only about $1 \%$ of all TNC have been presented on the Ukrainian market. Together with large national business TNCs provides more than $80 \%$ of GDP occupying less than $20 \%$ of working citizens, which is the perfect illustration of the Pareto's law in the Ukrainian economy. In the same time, the percentage of GDP of MSB is the positive indicator of economic development, thus it should increase.

World leader auditing companies, as well as many economists and financial experts, dedicated numerous reports, studies, articles and books for the creation and estimation of effective models of business development and investment attractiveness. In spite of the role of CSR in the social welfare maintaining, it may become an effective tool for the innovative development of the company and lead to the improvement of its corporate financial performance (CFP). As an example of the best world practice, CSR may be considered as one of the instruments for the progressive development of the Ukrainian economy. Moreover, during the ongoing changes in politics and the development of liberal democracy, the business has possibilities to become one of the social regulators. Thereby the studying of the potential innovative role of CSR in the development of the social sector, CFP, investment attractiveness and Ukrainian economic situation is topical research direction. At the same time, there is a great lack of empirical studies dedicated to the CSR levels in Ukraine thereby this research is first to provide relevant information and critical analysis about how strong is CSR implemented into Ukrainian business practice.

The aim of the study is to estimate the role of corporate social responsibility in the innovative development and international diversification of the companies regarding their corporate financial performance by analyzing most relevant publications and main economic indicators of the largest national and international companies of the Ukrainian market.

Literature Review. Economic scholar provides us with many definitions of corporate social responsibility. According to Elhauge, CSR could be described as a process of sacrificing profits in social interests (Elhauge, 2005). Simple and easy to memorize, this definition creates a great misunderstanding between CSR and patronage or charity. To understand what CSR really means, one should remember the fundamental principle - «CSR is not about how profit is spent, it is about how profit is earned». Academic publications explain CSR in several ways. In general, it is rational feedback of the system to the conflicting expectations of interested parties (stakeholders), which aims to achieve sustainable development of the firm. It is the responsibility of those who make decisions before those, who are influenced by these decisions. According to Frooman, a whole CSR strategy could be divided into its composing part - CSR actions. The author defines it as an action by a firm, which the firm chooses to take, that substantially affects an identifiable social stakeholder's welfare (Frooman, 1997).

The roots of CSR lies in the $50^{\text {th }}$ of 20 century when US businessmen, among them Henry Ford, firstly announced a concept that business has to serve society. Being the brand new way of understanding of the companies social role, CSR has passed the long way to be considered as an innovative strategy of business development. This point of view has emerged as a consequence of a new understanding of the social role of the corporation and creates a phenomenon of the social order on the CSR. M. Friedman in his article «The Social Responsibility of Business Is to Increase Its Profits» justify the social role of the corporation by creating the concept of the legal purpose of the corporation telling us that in a freeenterprise, private property system, a corporate executive is an employee of the owners of the firm. This person has a direct responsibility to his employers. Responsibility to conduct the business in accordance 

Review and Empirical Study from Ukraine

with their desires than generally consists of making as much money as possible not confronting the basic rules of the society.

Integrating theories of CSR are guided by the rule - «no society, no business». Corporates are ought to invest in the development of society to increase the loyalty of buyers to its products and services. The very ambitious aim of CSR in case of large national business is to increase the purchasing power of citizens with simultaneous creation of positive reputation and interest in end users. According to the IBM Global CEO Study in 2006, corporate responsibility became one of the five basic preconditions for the successful organization of the future. CSR has received strong support from the numerous global organizations including the UN and has become one of the key factors of sustainable development. Its main reason is the strong role of large national business and transnational corporations on the climate changes, number of workplaces, the economy of developing countries, minimum wage etc. TNCs and large business's potential consists in being not only part of these problems but also a part of the solution (Kolk and van Tulder, 2010). Half a century ago socially responsible business had been just an idea of several entrepreneurs and scientists but managed to raise into an organizational and ideological basis for sustainable development and internationalization of contemporary companies.

Academic scholars express a different opinion whether CSR influences on the corporate financial performance but most agree that it has a direct positive correlation with overall firm's financial performance. Overview and critical analysis of these studies are presented in the next section of this article. Several authors dedicated their papers to the explanations of the positive link between CSR and CFP. Waddock and Graves hypothesized that socially irresponsible politics of the firm in attempts to minimize implicit cost e.g. lowering product quality, use of outdated manufacturing technologies, leads to the rise of explicit costs such as interest payments to bond holders (Waddock and Graves, 1997). The same authors continue with the statement that investments cost into CSR development are noncomparable lesser than a positive impact on financial performance. Preston and O'Bannon substantiated the "social impact hypothesis", which has a link with «stakeholders theory» and suggests that meeting the needs of ordinary stakeholders leads to the positive impact on financial performance (Preston and O'Bannon, 1997). Another point of view is connected to the relationship between slack resources, good management and CSR that creates a «virtuous circle» between CSR and CFR. The important issue is the demand for CSR that could be consumer-related and stakeholders-related. This theory means that even if firm acts in a non-irresponsible way but does not implement any CSR standards may suffer from liabilities (McWilliams and Siegel, 2001) that consider CSR as a vital component for the innovative and successful development of the firm.

The relationship between CSR and investment attractiveness $(I A)$ is more controversial comparing to the link between CSR and CFP. The cause of this controversy is primary in the lack of appropriate studies that hinders scientists to perform meta-analyses and provide business society with a certain conclusion. Following Jac and Vondrackova, IA may be defined as the list of factors that influence a business entity when making its investment decisions. In the country level case, IA reflects how interesting the relevant territory, area or region is to businesses (Jac and Vondrackova, 2017). Knox and Maklan put the relationship between CSR and IA into the list of main assertions and beliefs about business (Knox and Maklan, 2004). Moreover, Zadek mentioned that only $4 \%$ of the total funds available for stock market investment are governed by CSR principles and standards, thus, most enterprises judged not to implement CSR into their activity still have full access to equity funding (Zadek, 2002). In the same time, some other studies have shown a clear relationship between corporate social responsibility and the investment efficiency of the firm (Benlemlih and Bitar, 2016).

Being an innovative management strategy widely used in US and European companies, CSR still provokes many controversies about its impact on the profitability of the company. High level of debates around the influence of corporate social responsibility on the firm financial performance and the uncertainty 

Review and Empirical Study from Ukraine

about the link between CSR and investment attractiveness of the corporation prompted to overview and analyze the main studies around this topics. For the literature review most cited publications dedicated to the problem of the relationship between CSR, corporate financial performance (CFP) and investment attractiveness (IA) were considered. The article search was performed through Google Scholar search tool by the key words "corporate social responsibility», "profitability», "corporate social performance», «stakeholder management», «corporate financial performance», «investment attractiveness», «investment effectiveness», «risk management». Predominantly meta-analysis and large empirical or case studies with high rates of citations were included in the research. Ten most illustrative studies have been chosen to show the leading opinions on the relationship between CSR and CFP.

E. Kenneth et al. (1985) in the four-component survey «An Empirical Examination of the Relationship between Corporate Social Responsibility and Profitability» stated no statistically significant relationship between a strong orientation toward social responsibility or concern for society and financial performance. It was neither beneficial nor harmful for a firm to be socially motivated to fulfil its social contract (Kenneth et al., 1985). Coombs and Gilley found out that stakeholder management tended to reduce the positive effects of financial performance on the various types of compensation. No positive relationship was found between CSR, financial performance and CEO compensation (Coombs and Gilley, 2005).

Famous researcher on CSR J. Frooman in his meta-analysis of 27 studies dedicated to the link between CSR and profitability proves that acting in a socially irresponsible way leads to the decrease in the shareholders' welfare. Among many factors, socially responsible behavior is necessary to increase stock value and shareholders wealth. Only economic self-interest may drive the firm to act in social responsibility and law-abiding way. Concluding - increase in shareholders welfare is an objective reason for firms to implement CSR into its activity (Frooman, 1997). Key and Popkin in the case study "Integrating ethics into the strategic management process: doing well by doing good" investigated that the inclusion of ethical criteria and corporate social responsibility into strategic management in before-profit rather than after-profit activities may maximize corporate profits (Key and Popkin, 1998). Case study of US bank industry conducted by Simpson and Kohers showed a strong positive correlation between CSR and the level of return of assets. The difference in profitability between the banks with high CSR performance and the banks with lower CSR performance was statistically significant. The value of loan losses was also significantly lower in banks with outstanding CSR comparing to the banks with low social performance (Simpson and Kohers, 2002). McWilliam and Siegel considered CSR as am an obligatory part of firms activity due to the existence of consumers' and stakeholders' demand on it. Depending on the size of firm, level of diversification and development, advertising and image, government sales, consumer income and social circumstances, labor market conditions, and stage of the industry, it becomes possible to calculate appropriate size of the investments into CSR for the most effective impact (McWilliams and Siegel, 2001). Roberts and Dowling provide us with the evidence that corporations with better corporate reputations are better able to sustain superior financial performance outcomes over time. In the same time, superiorperforming firms with a good-reputation have a greater chance of sustaining superior performance long while. Good reputation assists loss-making enterprises to return to the profitability (Roberts and Dowling, 2001). In 2003, Orlitzky and co-authors conducted a large meta-analysis that incorporated 52 studies related to the link between CSR and CFP. Results showed that corporate social responsibility and in less extend environmental responsibility positively correlates with overall firm's financial performance. This relationship tends to be bidirectional and simultaneous. Corporate relationship and image appear to be an important precondition of such a relationship. In spite of the large amount of «pros» in favour of the positive relationship between CSR and CFP, still, some scientists doubt about the reliability of pieces of evidence. For example, Griffin and Mahon in their research «The Corporate Social Performance and Corporate Financial Performance Debate: Twenty-Five Years of Incomparable Research» found out that Chosen indexes and measurement systems may predetermine the results of the study - CSR/CFP relationship. 

Review and Empirical Study from Ukraine

While Fortune and KDL indicate close track between these CSR and CFP, TRI and corporate philanthropy failed to find the relationship between corporate social responsibility and the firm's financial performance (Griffin and Mahon, 1997). Rowley and Berman concluding their critical review of available data mentioned that researchers should pay attention to the reasons (social, psychological) for higher stakeholders' loyalty to those firms that implement CSR standards into their activity. Most of the variables in studies dedicated to the relationship of the CSR and CFP are hard to compare thus the results of meta-analysis may be biased (Rowley and Berman, 2000).

Limited amount of studies about the cross relationship between CSR and IA are available up to date. All of them directly or indirectly declares the positive influence of corporate social responsibility on the investment attractiveness and effectiveness. For example, Benlemlih and Bitar found out that CSR is linked to higher investment efficiency. Dimensions linked to the primary stakeholders - employee relations, diversity and product characteristics, environment protection, - play the most important role in improving investment efficiency. During the financial crisis, CSR enhances customer loyalty to firms, which use CSR standards in their activity. The extremely low or extremely high levels of CSR do not lead to an increase in investment efficiency (Benlemlih and Bitar, 2016). The investigation of Cohen et al. has shown that retail investors are most concerned with economic performance information, followed by governance, and on the third place - corporate social responsibility. Responders who by the moment of the study held socially responsible investment preferred to use all three types of information comparing to those, who didn't hold socially responsible investment (Cohen et al. 2011). Interesting results appeared in the investigation of the relationships between corporate social responsibility and earning management (accounting fraud) (EM) across 1,653 companies in 46 countries. Type of relationship between CSR and EM depends on which EM is considered. An increase in CSR is connected to the increase in earning aggressiveness. In the same time earning losses avoidance and earning smoothing have shown a negative correlation with CSR levels. Thus in the case of mitigating earning aggressiveness by strong enforcement, CSR in the complex may lead to the overall decrease in the EM levels (Chih et al., 2008). El Ghoul et al. proved that firms with better corporate social responsibility performance enjoy the significantly lower cost of equity capital. Responsible employee treating, environmental and product policies contribute to lowering cost of equity of such firms, responsible actions on community relations, diversity and human rights do not contribute to the decrease in the cost of equity (El Ghoul, 2010). Two meta-analyses dedicated to the relationship between CSR and CFP have demonstrated the strong positive impact of the social responsibility activity on the firm's overall profitability. In addition, many other studies also have shown similar results. However, two articles failed to find the relationship between CSR and CFP and some authoritative publications didn't document any certain conclusion. The amount of data about the influence of CSR on investment effectiveness and attractiveness does not permit to make any tough statements. A limited number of research declares the positive impact of CSR standards on the different indicators connected to the investment attractiveness. In spite of the small number of studies, at least no one of them shows a negative connection between CSR and IA. This data should be kept in mind to prevent the overestimation of expected influence of CSR on the financial indicators of the company that is an integral part of innovative strategic management.

Methodology and research methods. First 100 companies from the list of Top-200 Ukrainian largest firms 2017 were included in the study. The rating was developed by the business analytical information agency censor.net on the basis of data that included companies annual revenue, profit/loss ratio, activity and type of ownership. The exclusion criteria stated ownership and absence of relevant information about the company (no official web-page, outdated general information on the official web-page). Two indicators were estimated - the presence of the information about CSR/sustainable development programs and the presence of the annual or periodical (several years) reports about CSR/sustainable development programs. No information on official web-page about CSR/sustainable development was estimated as no 
V. Fadyeyeva. Corporate Social Responsibility as the Basis of Innovative Development of Modern Companies: Literature Review and Empirical Study from Ukraine

CSR programs in the company. All companies were divided into two groups: \#1 - TNCs and their subsidiaries; \#2 - other, mainly large national business. Descriptive statistics were used to describe the distribution of results. Difference between the groups was calculated by $x^{2}$-criterion and $p$-value on SPSS Statistics 23.

Results. After the exclusion of 12 enterprises with state ownership and 5 without relevant information, 83 companies composed 2 study groups: \#1 - TNCs and their subsidiaries, - 21 companies, and \#2 other, -62 companies (see - Figure 1). Table 1 and pie chart 1 show the distribution between the industry sectors.

Table 1. Distribution between the industries

\begin{tabular}{|c|c|c|c|c|c|c|c|}
\hline \# & Industry sector & $\begin{array}{c}\text { Number of } \\
\text { companies }\end{array}$ & $\mathbf{\%}$ & $\mathbf{\#}$ & $\begin{array}{c}\text { Industry } \\
\text { sector }\end{array}$ & $\begin{array}{c}\text { Number of } \\
\text { companies }\end{array}$ & $\%$ \\
\hline $\mathbf{1}$ & Agricultural industry & 21 & $25,30 \%$ & $\mathbf{6}$ & Transport & 3 & $3,60 \%$ \\
\hline $\mathbf{2}$ & $\begin{array}{c}\text { Mining and } \\
\text { metallurgy }\end{array}$ & 20 & $24 \%$ & $\mathbf{7}$ & IT & 2 & $3,60 \%$ \\
\hline $\mathbf{3}$ & Power engineering & 17 & $20,50 \%$ & $\mathbf{8}$ & Engineering & 1 & $1,30 \%$ \\
\hline $\mathbf{4}$ & Retail & 10 & $12 \%$ & $\mathbf{9}$ & $\begin{array}{c}\text { Chemical } \\
\text { industry }\end{array}$ & 1 & $1,30 \%$ \\
\hline $\mathbf{5}$ & Distribution & $\mathbf{8}$ & $9,60 \%$ & \multicolumn{4}{|c}{} \\
\hline
\end{tabular}

Sources: systemized by the author on the basis of statistical data (censor.net, 2017).

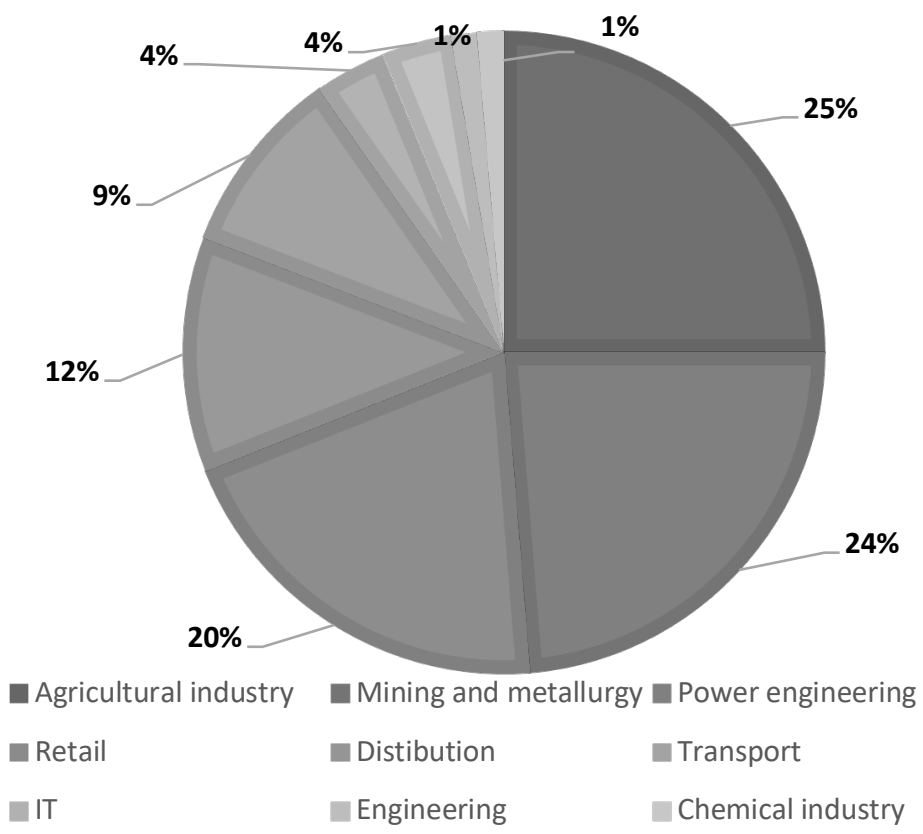

Figure 1. Distribution between industrial sectors.

Sources: systemized by the author on the basis of statistical data (censor.net, 2017).

Table 2 shows the results of the analysis of CSR implementation in the main companies of the Ukrainian industry. 
V. Fadyeyeva. Corporate Social Responsibility as the Basis of Innovative Development of Modern Companies: Literature Review and Empirical Study from Ukraine

Table 2. CSR in the companies of the Ukrainian market

\begin{tabular}{|c|c|c|c|c|}
\hline Indicators & $\begin{array}{c}\text { Group \#1, } \\
\text { numbers }\end{array}$ & Group \#1, \% & $\begin{array}{c}\text { Group \#2, } \\
\text { numbers }\end{array}$ & Group \#2, \% \\
\hline CSR reports $^{*}$ & 15 & $71,40 \%$ & 17 & $27,40 \%$ \\
\hline $\begin{array}{c}\text { Description of CSR } \\
\text { on web-page }\end{array}$ & 3 & $14,30 \%$ & 21 & $33,80 \%$ \\
\hline None $^{*}$ & 3 & $14,30 \%$ & 24 & $38,80 \%$ \\
\hline
\end{tabular}

Sources: developed by the author on the basis of CSR reports revealed by the companies on their official web-pages.

As it is shown in Table 2, most TNCs demonstrate a higher level of involvement into corporate social responsibility than large national business. $2 / 3$ of them reveal annual or periodical reports about their CSR programs, main directions and the implication of the UN Goals of Sustainable Development.

Pearson test showed the presence of a difference between two groups with very high statistical significance $-p=0,0005\left({ }^{*}-\right.$ in Table 2$)$.

As it is shown in Figure 2, 3/4 of Ukrainian market giants belongs to the national corporations that in the same time shows significantly lower rated of corporate social responsibility.

Currently, it is not clear whether CSR is primary or secondary to better financial performance but it is beyond controversy that CSR has become an integral part of the international strategy of companies, their market-wide spreading.

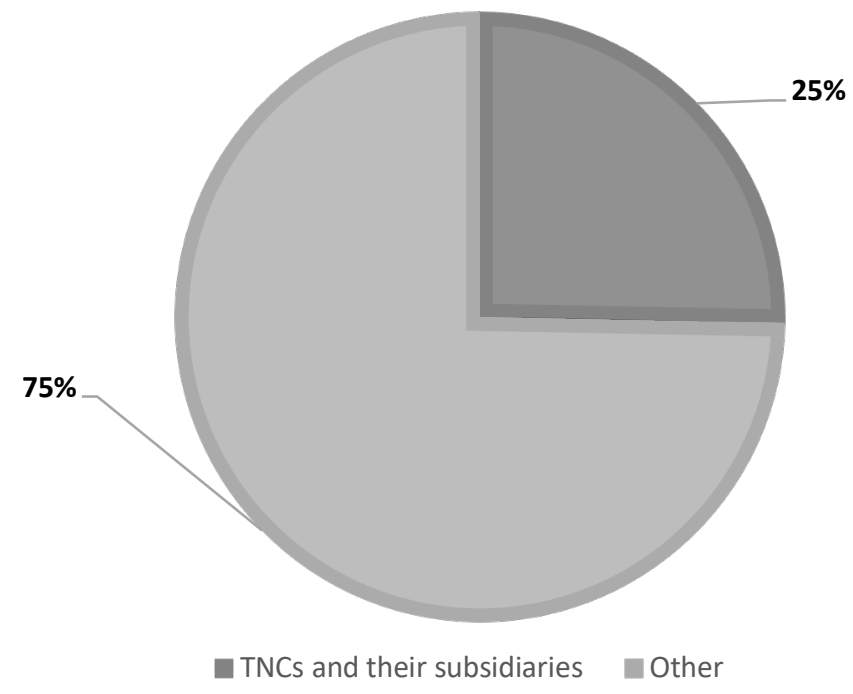

Figure 2. The distribution between TNCs with subsidiaries and other companies.

Sources: systemized by the author on the basis of statistical data (censor.net, 2017)

It should be noted that currently only 56 Ukrainian companies, NGOs, organization and academics are valid members of the UN Global Compact. Among them - only 8 enterprises from Top-200 Ukraine 2017. At the same time, the lion's share of largest Ukrainian companies - 70\% belongs to the agricultural, mining and metallurgy, power engineering industries that strongly affects the environment and 

Review and Empirical Study from Ukraine

stakeholders. Therefore, primary measures of social responsibility should become an integral part of corporate strategy.

Conclusions. The current study is divided into two parts - first, theoretical is dedicated to the influence of corporate social responsibility on the financial performance and investment attractiveness of the firm; and second, empirical, describes the current prevalence of CSR in the biggest companies of the Ukrainian market, its prevalence in national and international companies.

Starting from $50^{\text {th }}$ of 20 century many scientists, top economists and financier tried to answer the question about the connection between CSR, CFP an IA. Up to date the bigger part of the pieces of evidence declares the positive correlation between CSR and CFP. However, still, some studies failed to confirm this correlation. Therefore, issues about CSR/CFP relationship remains partly uncertain. Limited number of papers clarify the connection between CSR and IA. Their results strongly suggest that CSR has a positive impact on the investment climate and investment attractiveness. Fruxell and Wang made a fair comment: «Overall perception of the firm and its image rather than the actual action taken by the firm may be the dominating factor in determining the firm's relative ranking of its social performance» (Fryxell and Wang, 1994). Therefore, the possible cause of the positive correlation between CSR and CFP may be due to the influence of the firm image rather than the actual CSR rating. According to the English etymology dictionary, «image» means 1) piece of sculpture, a statue; 2) artificial reproduction that looks like a person or thing. In general, the image refers us to the result of the combination of a purposefully created vision of a person/company/country combined with our subjective perception of e reality. This hypothesis is supported by several studies mentioned in the literature review. A second possible explanation of these contradictions may be connected to the pressure that is caused by the social role of CSR. UN global compact and goals of sustainable development, ISO 26000, Equator Principles, UN Principles for Responsible Investment, World Bank IFC's Environmental and Social Standards etc. dictate terms for business management and development. Not only world-leading organizations dictate these terms but also a society in whole drives corporates to be socially responsible. That is why the question about social order on CSR remains very topical for future research. Ignoring polemic about direct financial influence of CSR, CEOs and managers ought to consider it as an integral part of innovative strategies at least because of its strong image-making impact. An empirical study of the largest Ukrainian companies showed that levels of CSR significantly differs between TNCs with subsidiaries and national large business. Only $1 / 3$ of the second group provides the annual and periodical reports about CSR activity at the firms. Other parts only declare different projects on their web-pages but no further information is provided (for example financial report). Moreover, the last 1/3 doesn't show any information about CSR. Vice versa, most international companies had a strong concern about CSR. That means that international diversification inextricably linked with socially responsible ideology and activity or at least declaration of these ideas. The results of study combined with the literature data should promote the development of corporate social responsibility in large Ukrainian business by clarifying the importance of CSR and its highly probable positive impact on the economic performance of the firms. On another hand, the reader should understand the strong limitation of the study because of its mainly descriptive character. Unfortunately, the lack of analytical data about Ukrainian companies e.g. different CSR indexes makes it impossible to accurately measure the actual prevalence of CSR in Ukraine. Therefore, further studies should be carried out.

\section{References}

Aupperle, K. E., Carroll, A. B., \& Hatfield, J. D. (1985). An empirical examination of the relationship between corporate social responsibility and profitability. Academy of management Journal, 28(2), 446-463.

Benlemlih, M., \& Bitar, M. (2018). Corporate social responsibility and investment efficiency. Journal of Business Ethics, 148(3), $647-671$

Chih, H. L., Shen, C. H., \& Kang, F. C. (2008). Corporate social responsibility, investor protection, and earnings management: Some international evidence. Journal of business ethics, 79(1-2), 179-198. 
Cohen, J., Holder-Webb, L., Nath, L., \& Wood, D. (2011). Retail investors' perceptions of the decision-usefulness of economic performance, governance, and corporate social responsibility disclosures. Behavioral Research in Accounting, 23(1), 109-129.

Coombs, J. E., \& Gilley, K. M. (2005). Stakeholder management as a predictor of CEO compensation: Main effects and interactions with financial performance. Strategic Management Journal, 26(9), 827-840.

El Ghoul, S., Guedhami, O., Kwok, C. C., \& Mishra, D. R. (2011). Does corporate social responsibility affect the cost of capital?. Journal of Banking \& Finance, 35(9), 2388-2406.

Elhauge, E. (2005). Sacrificing corporate profits in the public interest. NyUL Rev., 80, 733.

Friedman, M. (2007). The social responsibility of business is to increase its profits. In Corporate ethics and corporate governance (pp. 173-178). Springer, Berlin, Heidelberg.

Frooman, J. (1997). Socially irresponsible and illegal behavior and shareholder wealth: A meta-analysis of event studies. Business \& society, 36(3), 221-249.

Fryxell, G. E., \& Wang, J. (1994). The Fortune corporate'reputation'index: Reputation for what?. Journal of management, 20(1), $1-14$.

Garriga, E., \& Mele, D. (2004). Corporate social responsibility theories: Mapping the territory. Journal of business ethics, 53(12), 51-71.

Griffin, J. J., \& Mahon, J. F. (1997). The corporate social performance and corporate financial performance debate: Twenty-five years of incomparable research. Business \& society, 36(1), 5-31.

ISO 26000 - Social responsibility. URL: https://www.iso.org/iso-26000-social-responsibility.html

Jac, I., \& Vondrackova, M. (2017). The perception of selected aspects of investment attractiveness by businesses making investments in the Czech Republic. Economics and Management.

Key, S., \& Popkin, S. J. (1998). Integrating ethics into the strategic management process: Doing well by doing good Management Decision, 36(5), 331-338.

Knox, S., \& Maklan, S. (2004). Corporate social responsibility: Moving beyond investment towards measuring outcomes. European Management Journal, 22(5), 508-516.

Kolk, A., \& Van Tulder, R. (2010). International business, corporate social responsibility and sustainable development. International business review, 19(2), 119-125.

McWilliams, A., \& Siegel, D. (2001). Corporate social responsibility: A theory of the firm perspective. Academy of management review, 26(1), 117-127.

Mueckenberger, U., \& Jastram, S. (2010). Transnational norm-building networks and the legitimacy of corporate social responsibility standards. Journal of Business Ethics, 97(2), 223-239.

Orlitzky, M., Schmidt, F. L., \& Rynes, S. L. (2003). Corporate social and financial performance: A meta-analysis. Organization studies, 24(3), 403-441.

Pohle, G., \& Chapman, M. (2006). IBM's global CEO report 2006: business model innovation matters. Strategy \& Leadership, 34(5), 34-40.

Preston, L. E., \& O'bannon, D. P. (1997). The corporate social-financial performance relationship: A typology and analysis Business \& Society, 36(4), 419-429.

Report of the World Commission on Environment and Development: Our Common Future. URL: http://www.undocuments.net/our-common-future.pdf

Review of Equator Principles: https://equator-principles.com/ep4/

Roberts, P. W., \& Dowling, G. R. (2002). Corporate reputation and sustained superior financial performance. Strategic management journal, 23(12), 1077-1093.

Rowley, T., \& Berman, S. (2000). A brand new brand of corporate social performance. Business \& Society, 39(4), 397-418.

Simpson, W. G., \& Kohers, T. (2002). The link between corporate social and financial performance: Evidence from the banking industry. Journal of business ethics, 35(2), 97-109.

Small and large business in provides near $80 \%$ of working places in Ukraine. URL: https://www.unian.ua/business/1728091maliy-i-seredniy-biznes-v-ukrajini-zabezpechue-mayje-80-robochih-mists-minekonomrozvitku.html

The Nine Principles of the Global Compact. URL: https://www.unglobalcompact.org/system/attachments/7618/original/ Zenith.pdf?1282019232

Top-200 largest Ukrainian companies 2017. URL: https://biz.censor.net.ua/resonance/3084420/200_nayiblshih_kompanyi_ ukrani_2017_roku

UN Principles for Responsible Investment: https://www.unpri.org/

United Nations Global Compact. URL: https://www.unglobalcompact.org/what-is-gc

Waddock, S. A., \& Graves, S. B. (1997). The corporate social performance-financial performance link. Strategic management journal, 18(4), 303-319.

World Bank IFC's Environmental and Social Standards: https://www.ffc.org/wps/wcm/connect/Topics_Ext_Content/IFC_ External_Corporate_Site/Sustainability-At-IFC/Policies-Standards/Performance-Standards

Zadek, S., \& Raynard, P. (2002). Stakeholder engagement: measuring and communicating quality. Accountability Quarterly, 19(2), 8-17. 
V. Fadyeyeva. Corporate Social Responsibility as the Basis of Innovative Development of Modern Companies: Literature Review and Empirical Study from Ukraine

В. Е. Фадєєєа, Університет імені Адама Міцкевича в Познані (Польща).

Корпоративна соціальна відповідальність як основа інноваційного розвитку сучасних підприємств: огляд літератури та емпіричне дослідження досвіду України

Будучи сучасною та інноваційною стратегією, корпоративна соціальна відповідальність (КСВ) вже зарекомендувала себе як ефективний інструмент для створення позитивного іміджу компанії серед стейкхолдерів та споживачів. Проте прямий економічний вплив КСВ, наприклад його взаємозв'язок з корпоративними фрінансовими показниками, залишається не до кінця зрозумілим. Таким чином, дана стаття підсумовує тривалу дискусію про вплив КСВ на корпоративні фрінансові показники ідемонструє поточний стан КСВ у найбільших компаніях українського ринку. Основною метою дослідження є оцінка ролі КСВ в інноваційному розвитку та міжнародній диверсифікації компаній з урахуванням показників корпоративної фінансової діяльності шляхом аналізу найбільш актуальних публікацій та основних економічних показників найбільших національних та міжнародних компаній українського ринку. Об'єктом дослідження є КСВ у світі та в Україні. Стаття складається з двох частин - теоретичної та емпіричної. Для теоретичного аналізу був проведений огляд літератури за допомогою інструмента пошуку Google Scholar за ключовими словами, пов'язаними з КСВ; до емпіричного аналізу рівнів КСВ було включено 100 найбільших українських компаній за версією Топ-200 Україна 2017. Оцінювалися два показники - наявність на офріційних веб-сторінках компаній інфрормації про програми КСВ / сталого розвитку та наявність щорічних або періодичних звітів про програми з КСВ / cmaлого розвитку. Після виключення 12 підприємств з державною формою власності та 5 без відповідної інформації, 83 компанії були розділені на 2 групи: №1 - транснаціональні корпорації (ТНК) та їхні дочірні компанії (21 підприємство) та № 2 - інші (62 компанії). Результати огляду літератури показали, що на сьогодні більша частина доказів свідчить про позитивний зв'язок КСВ та корпоративних фрінансових показників. Проте деякі дослідження не змогли підтвердити цю кореляцію, тому дана проблематика лишається частково невизначеною. Водночас всі автори визнали, що сьогодні КСВ є однією з основних складових інноваційних стратеаій розвитку. Емпіричне дослідження показало, що рівень КСВ істотно відрізняється між ТНК, їхніми дочірніми підприємствами та українським великим бізнесом $(p=000,5) 3$ вищими рівнями у першій групі. Таким чином, КСВ можна розәлядати як невід'ємну частину інноваційного менеджменту та міжнародної диверсифікації компанії. Ця стаття висвітлює одне 3 небагатьох досліджень сучасного стану КСВ в Україні, підкресливши важливий напрямок подальших пошуків у сфері КСВ. Поряд із науковим значенням, результати цього дослідження можуть бути корисними для фрахівців у сфері стратегічного планування, керівників компаній, фрінансових менеджерів.

Ключові слова: корпоративна соціальна відповідальність, стандарти, корпоративні фінансові показники, інвестиційна привабливість.

Manuscript received: 11.02.2019.

(C) The author(s) 2019. This article is published with open access at Sumy State University. 